\title{
SÕNAALGULISE /h/ HÄÄLDUS SAMADEL KÕNELEJATEL AVALIKUS JA ARGISUHTLUSES
}

\author{
Pire Teras \\ Tartu Ülikool
}

\begin{abstract}
Ülevaade. Selles artiklis käsitletakse sõnaalgulise /h/ hääldamist. Varem tehtud uurimused on osutanud /h/ häälduse olenemisele suhtlusolukorrast: argisuhtluses jääb $/ \mathrm{h} /$ tihti hääldamata, aga teksti lugedes ja avalikus suhtluses juhtub seda pigem harva. Lisaks suhtlusolukorrale on leitud muidki /h/ hääldust mõjutavaid tegureid. Tähelepanu ei ole aga pööratud sellele, kuivõrd varieerub /h/ hääldus samal kõnelejal eri suhtlusolukorras. Kaheksa keelejuhi häälduse analüüs näitab, et kõik häl̈ldavad /h/-d rohkem avalikus kui argisuhtluses. Peamiseks /h/ hääldamist mõjutavaks teguriks osutus sõna lauserõhulisus: /h/-d hääldatakse oluliselt sagedamini rõhulistes kui rõhututes sõnades. Rõhuliste sõnade puhul oli keelejuhtide vahel oluline erinevus: kaks keelejuhti hääldas $/ \mathrm{h} /$-d teistest oluliselt vähem (enim rõhulistes sõnades pärast pausi ja vokaaliga lõppevat sõna ning harva esinevates sõnades), teised hääldasid $/ \mathrm{h} /-\mathrm{d}$ pea alati avalikus suhtluses ning argisuhtluses enim lausungialgulistes ja -lõpulistes sõnades. Rõhututes sõnades hääldas enamik keelejuhte $/ \mathrm{h} / \mathrm{d}$ oluliselt rohkem avalikus suhtluses ning argisuhtluses hääldasid kõik kõnelejad /h/-d oluliselt rohkem pärast pausi.
\end{abstract}

Märksõnad: foneetika, sõnaalguline /h/, varieerumine, eesti keel

DOI: https://doi.org/10.12697/jeful.2019.10.1.11

\section{Sissejuhatus}

Eesti keeles on suur hulk sõnu, mis kirjapildis algavad $h$-ga. $/ \mathrm{h} /$ on helitu kõri-suu-hõõrdhäälik, mis on häälduses lühikesena nõrk ja sageli heliline (Eek ja Meister 1999: 542). On üldteada, et suulises suhtluses jääb /h/ sõna alguses sageli häl̈ldamata, nt hea [ea:], hakkan [ak:kan], homme [om:me]. Sõnaalgulise $/ \mathrm{h} / \mathrm{hääldamise} \mathrm{varieerumist} \mathrm{ja} / \mathrm{h} / \mathrm{häälda-}$ mata jätmist märkasid juba 17. sajandil eesti keele grammatikate kirjutajad (vt nt Göseken 1660: 4). Oli ka tähelepanekuid, et $/ \mathrm{h} /$ esineb siiski mõne Eesti piirkonna häälduses, nt Räpina (Hupel 1780: 2) või üldisemalt Võru ja Tartu häälduses (Masing 1824: 17), aga ka haritud inimeste häälduses (Masing 1824: 17). 20. sajandil on säilinud sõnaalgulise 
/h/-ga murdealadena nimetatud Võru murret, Hiiumaal Pühalepa murrakut, Saaremaal Kihelkonna murrakut ja rannamurdes Kuusalu murrakut, kuid kahest viimasest oli sõnaalguline /h/ sajandi teises pooles hääldusest kadumas (Kask 1972: 98).

Eelmise sajandi algupoolel arutati aktiivselt selle üle, kas sõnaalgulist /h/-d ikka kirjutada ja kui, siis milliste sõnade algusse see kirjutada (vt selle kohta ülevaadet Cui 1999: 22-27). Paul Ariste (1936: 206-207) leidis, et olulisem on arutada hääldamise kui kirjutamise üle ja et ei saa pidada kohustuslikuks sõnaalgulise /h/ hääldamist olukorras, kus suurem osa jätab selle hääldamata ja väiksem osa hääldab seda kas alati või mõnikord. Ta esitas ka vastuväiteid neile, kes olid leidnud, et /h/ hääldamata jätmine on ebakultuurne (on vanu kultuurkeeligi, kus $h$ on kadunud), võib põhjustada mittemõistmist (on suhteliselt vähe sõnu, kus see võib juhtuda), ei järgi kirjapildi järgi häl̈ldamise põhimõtet (nii on see nt ka palatalisatsiooni puhul) ega ole ilus (ilust lähtumine ei ole objektiivne).

Keelekorraldajad on pidanud $h$ kirjutamist sõna alguses siiski jätkuvalt vajalikuks, järgides ortograafia põhimõtetest traditsiooni- ja tähenduspõhimõtet, sest leidub mitmeid sõnapaare, kus /h/-st oleneb sõna tähendust, nt aru vs. haru, iiliti vs. hiiliti, ala vs. hala. See on õigekeelsusteema, millele pööratakse jätkuvalt tähelepanu nii käsiraamatutes (vt nt EKK 2007: O 12) kui ka põhikooli I astme eesti keele õpetuses (PRÕK 2018). Siiani on nii neid, kes leiavad, et /h/ hääldamine sõna alguses ei ole nõutav (nt Ehala 1998: 16, EKK 2007: O 12), kui ka neid, kes soovitavad seda kirjakeeles pigem hääldada (nt Kraut et al. 2000: 25, Hint 2004: 1241'). Kuigi puudub kindel hääldusnõue, tõdeb Karl Pajusalu (1997: 180-181), et arvatavasti nimetaks enamik eestlasi ühe 'madala rahvakeele' tunnusena just sõnaalgulise $h$ hääldamata jätmist ning 'peene' võimalikult kirjutamispäraselt hääldatud eesti keele tunnusena selle hääldamist.

Asjaolule, et avalikus suhtluses hääldataksegi sõnaalgulist $/ \mathrm{h} / \mathrm{-d}$ järjekindlamalt kui argisuhtluses, osutavad nii varem tehtud akustilisfoneetilised uurimused (Mesipuu 2007 ning Kalvik ja Piits 2015) kui ka sotsiofoneetiline uurimus (Cui 1999). Kaili Cui (1999: 30-33) järgi hääldasid kõnelejad sõnaalgulise /h/ avalikus suhtluses välja kõigil või

1 Hint (2004: 124) möönab, et kui kõnelejale on sõnaalgulise $h$ hääldamine raske, võiks selle üldse hääldamata jätta. 
pea kõigil juhtudel, argisuhtluses aga keskmiselt 63\% juhtudest (sealjuures oli neid, kelle häälduses oli /h/ osakaal 20\%, ning neidki, kes hääldasid /h/ välja pea kõigil juhtudel). Margit Mesipuu (2007: 22, 27, 43) järgi hääldas üks kõneleja avalikus ettekandes $/ \mathrm{h} /-\mathrm{d} 90 \%$ juhtudest ja kaks kõnelejat argisuhtluses 44\% ja 52\% juhtudest. Cui (1999: 30) on põhjendanud $/ \mathrm{h} /$ hääldamise kõrget osakaalu avalikus suhtluses prestiižsusega (vt prestiiži kohta Paldre 1995), mis haakub Karl Pajusalu ülal esitatud tõdemusega.

Seda, et /h/-d hääldatakse avalikus suhtluses tunduvalt rohkem kui argisuhtluses, kinnitab ka Tartu Ülikooli eesti keele spontaanse kõne foneetilisest korpusest ${ }^{2}$ (EKSKFK) tehtud otsing (17.06.2019), mille tulemused on toodud joonisel 1. Avalikus suhtluses on kõnelejad hääldanud sõnaalgulise /h/ välja 76\% juhtudest ehk $901 h$-algulisest sõnast ja argisuhtluses sellest tunduvalt vähem: $36 \%$ juhtudest ehk $5281 h$-algulisest sõnast. Avalikust suhtlusest veelgi vähem jääb sõnaalguline $/ \mathrm{h} /$ hääldamata siis, kui kõneleja loeb teksti ja $h$ on silma ees (5\% kõigist juhtudest $^{3}$ ) (Kalvik ja Piits 2015: 65, vt ka joonis 1).

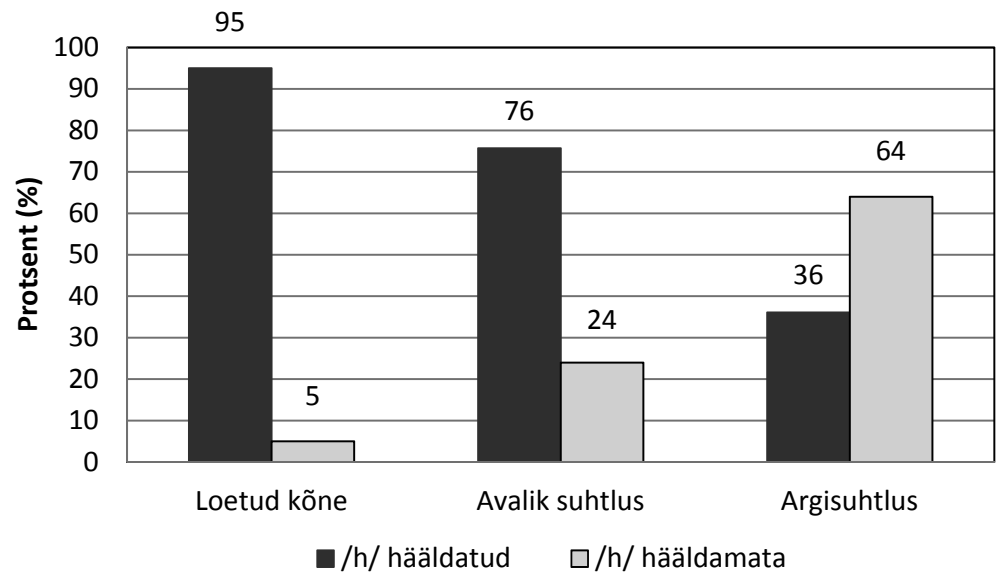

Joonis 1. Sõnaalgulise /h/ hääldamine loetud kõnes (Kalvik ja Piits 2015: 65), avalikus ja argisuhtluses (EKSKFK).

2 TÜ eesti keele spontaanse kõne foneetiline korpus (EKSKFK): https://www.keel.ut.ee/et/foneetikakorpus.

3 Cui (1999: 30-31) vaatas /h/ hääldust „Aktuaalse kaamera“ diktoritel ja leidis, et nad hääldasid /h/ välja isegi rohkem ehk $98 \%$ juhtudest. Ta põhjendas nii kõrget protsenti samuti sellega, et diktoritel on tekst silma ees ning et $h$ nägemine soodustab ka selle hääldamist. 
Suhtlusolukord paistab vägagi mõjutavat sõnaalgulise $/ \mathrm{h} / \mathrm{hääldamist}$ või mittehääldamist, kuid on leitud muidki tegureid, mis /h/ hääldamist mõjutavad; argisuhtluses näiteks sotsiaalsed tegurid, nagu kõneleja sugu, vanus, haridus, päritolu. Nii on Cui (1999: 42, 44, 46, 51-52) näidanud, et naised hääldavad /h/-d mõnevõrra rohkem kui mehed, noored ja keskealised kõnelejad mõnevõrra rohkem kui lapsed ja vanad, kesk- ja kõrgharidusega kõnelejad rohkem kui põhiharidusega kõnelejad ja $h$-lise murdetaustaga aladelt pärit kõnelejad rohkem kui $h$-ta murdetaustaga aladelt pärit kõnelejad. Keelelistest teguritest on argisuhtluses osutunud oluliseks näiteks tekstitüüp, isikunime alguses esinemine, sõna lauserõhulisus, esinemissagedus, häälikuline kontekst. Nii häl̈ldatakse sõnaalgulist /h/-d rohkem monoloogilises kui dialoogilises kõnes ja isiku- kui kohanimedes (Cui 1999: 54, 57). Samuti hääldatakse /h/-d rohkem lauserõhulistes sõnades, väikse esinemissagedusega sõnades või vokaaliga lõppeva sõna järel kui lauserõhututes, suurema esinemissagedusega sõnades või konsonandiga lõppeva sõna järel (Cui 1999: 59, 63, 69 ja Mesipuu 2007: 35-36).

Sõnaalgulise $h$ kadu või hääldamata jätmine ei iseloomusta ainult eesti keelt. Nii on näiteks $h$ kadunud eesti keele sugulaskeelest liivi keelest, esinedes seal vaid võõrsõnades või -nimedes (vt nt Viitso ja Ernštreits 2012). Kuigi romaani keeltes kirjutatakse traditsiooniliselt $h$ sõna alguses, jääb see seal hääldamata (Alkire ja Rosen 2010: 33). Germaani keeltes esineb sõnaalgulise $h$ hääldamata jätmist näiteks inglise murretes (vt nt Ramish 2010), kuid saksa keeles hääldatakse sõnaalgulist $h$-d üsna järjekindlalt. Frank Zimmerer ja Jürgen Trouvain (2015: 1924) on leidnud, et üksikutel juhtudel võib sõnaalguline $h$ jääda hääldamata siiski ka saksa keeles: pärast helilist häälikut jäi see hääldamata $1,3 \%$ ja pärast helitut konsonanti 3,7\% juhtudest, kuid lausungi alguses ei jäetud seda kunagi hääldamata. Samuti on näidatud, et hollandi spontaanses kõnes jäi /h/ hääldamata sagedates sõnades hebben 'olema, omama' ja het 'määrav artikkel/see' $68 \%$ juhtudest, kusjuures kolmandikul neist juhtudest sulghääliku järel (Schuppler et al. 2011: 106).

Varem eesti keele kohta tehtud uurimustes ei ole pööratud tähelepanu sellele, kuivõrd varieerub $/ \mathrm{h} /$ hääldus samal kõnelejal eri suhtlusolukorras. Selle artikli eesmärk ongi asjas selgust tuua. Samuti otsitakse vastust järgmistele küsimustele: millised on sõnaalgulise $/ \mathrm{h} /$ hääldusvariandid; millised on keelejuhtide erinevused sõnaalgulise $/ \mathrm{h} /$ 
hääldamisel; kuidas mõjutavad /h/ hääldust keelelised tegurid (sõna lauserõhulisus, sagedus, positsioon ja eelnev kontekst); millised tegurid eraldi või koos mõjutavad /h/ hääldust oluliselt?

\section{Materjal ja meetod}

Uurimismaterjal koguti Tartu Ülikooli eesti keele spontaanse kõne foneetilisest korpusest (EKSKFK). 2019. a jaanuari seisuga sisaldas korpus helifaile kogumahuga 94 tundi, millest sõna- ja häälikutasandil oli segmenditud 86 tundi. Korpuses on kõnet kokku 134 keelejuhilt. Neist keelejuhtidest on kaheksat salvestatud nii avalikus kui ka argises suhtlusolukorras. Esimese puhul on tegemist monoloogina peetud loengu või ettekandega, mida võib pidada pigem poolspontaanseks kõneks, mis põhineb ettevalmistatud tekstil, kuid enamiku kõnelejate puhul ei ole siiski tegemist teksti lugemisega. Argise suhtlusolukorra puhul on tegemist tuttavate- või sõpradevahelise dialoogilise vestlusega. Keelejuhtidest neli on naised (KJ1, KJ2, KJ3 ja KJ4) vanuses 23-48 aastat (keskmine vanus 36,7 a) ja neli mehed (KJ5, KJ6, KJ7 ja KJ8) vanuses 26-60 aastat (keskmine vanus 41,2 a).

Selle töö uurimismaterjal kogutigi nende kaheksa keelejuhi salvestistest. Kuna korpuse tekstifailides on sõnatasandi märgendamisel lähtutud eesti keele ortograafiast, sai skripti abil leida kõik $h$-algulistena kirjutatud sõnad. Kõigi kirjapildis $h$-alguliste sõnade hääldus täpsustati, kasutades kõneanalüüsi programmi Praat (Boersma ja Weenink 2016). Iga $h$-algulise sõna korral märgiti /h/ hääldusvariant (helitu, heliline või hääldamata), samuti märgiti keelejuht $\left(\mathrm{KJ} 1-\mathrm{KJ} 8^{4}\right)$, sotsiaalsetest teguritest keelejuhi sugu (mees, naine), keelelistest teguritest sõna esinemissagedus $^{5}$ (sage, harv), lauserõhulisus (rõhuline, rõhutu), asukoht lausungis (alguses, sees, lõpus), eelnev kontekst (paus, vokaal, heliline või helitu konsonant).

4 Kuna keelejuhte oli vähe ning praeguse liikuva eluviisi puhul on raske otsustada, milline piirkond on võinud keelejuhi hääldust enim mõjutada, jäeti mudelis sotsiaalsetest teguritest arvesse võtmata keelejuhi päritolupiirkond. Mõnel juhul oleks see määratlus langenud kokku keelejuhiga, sest mõnest piirkonnast on pärit vaid üks keelejuht.

5 Sõna loeti sagedaks, kui see kuulus „Foneetikakorpuse sagedussõnastiku“ 1000 sageda sõna hulka. 
Analüüsiti kokku 935 hääldusjuhtu, millest 477 avalikust suhtlusest ja 458 argisuhtlusest. Kuna keelejuhiti oli salvestuste kestus erinev, kogunes ka materjali erinev hulk. Keelejuhtide $h$-alguliste sõnade hääldusjuhtude arvud on toodud tabelis 1 .

Tabel 1. $h$-alguliste sõnade arv keelejuhiti avalikus ja argisuhtluses.

\begin{tabular}{lcc}
\hline Keelejuht & Avalik suhtlus & Argisuhtlus \\
\hline KJ1 & 39 & 44 \\
KJ2 & 35 & 30 \\
KJ3 & 63 & 49 \\
KJ4 & 214 & 148 \\
\hline KJ5 & 41 & 74 \\
KJ6 & 31 & 14 \\
KJ7 & 26 & 76 \\
KJ8 & 28 & 23 \\
Kokku & $\mathbf{4 7 7}$ & $\mathbf{4 5 8}$ \\
\hline
\end{tabular}

Statistilisel analüüsil kasutati programmi R (RStudio). Kirjeldavast statistikast kasutati protsentarvutust, analüüsides andmeid nii keelejuhiti kui ka keelejuhtide andmeid koos. Selleks et leida, millised tegurid eraldi või koos mõjutavad oluliselt $/ \mathrm{h} /$ hääldust, kasutati klassifitseerimispuu (ingl conditional inference tree) meetodit (klassifitseerimispuu moodustamiseks kasutati R-i paketis 'party' rakendatud funktsiooni ctree). Sellist meetodit sobib kasutada, kui andmestikus on sageduserinevused suured ja valimid eri suurusega, sest see suudab selliste probleemidega toime tulla (vt nt Ruutma et al. 2016: 102). Klassifitseerimispuu puhul on tegemist regressiooni- ja klassifitseerimismudeliga, mis põhineb rekursiivsel binaarsel ositamisel: algoritm testib, kas mõni sõltumatu muutuja on seotud uuritava muutujaga, ja leiab tugevaima seosega muutuja, tehes selles muutujas binaarse hargnemise ning korrates sellist protsessi järgmiste kahte alamhulka jagatud andmete peal seni, kuni ei ole jäänud ühtki sõltumatut muutujat, mis oleks oluliselt seotud uuritava muutujaga. Algoritmi antud $p$-väärtused näitavad, kui kindel võib olla igas hargnemises. (Levshina 2015: 291-292) 


\section{Tulemused ja arutelu}

Avalikus suhtluses hääldasid keelejuhid /h/-d keskmiselt $84 \%$ juhtudest (44\% helituna ja $40 \%$ helilisena), nii et $/ \mathrm{h} /$ jäi hääldamata $16 \%$ juhtudest. Argisuhtluses hääldati /h/-d aga tunduvalt vähem ehk $58 \%$ juhtudest (28\% helituna ja 30\% helilisena) ning $/ \mathrm{h} /$ jäi häldamata $42 \%$ juhtudest. Need /h/-ga hääldatud juhtude osakaalud on sarnased varem tehtud uurimuste tulemustega (Cui 1999 ja Mesipuu 2007), kuigi avaliku suhtluses on /h/-ga juhtude osakaal veidi väiksem, kuid samas suurem kui EKSKFK kõigist hääldusjuhtudest arvestades (76\%).

See, kas hääldatud $/ \mathrm{h} /$ variant oli helitu [h] või heliline $[\mathrm{h}]$, tulenes sõna esinemiskontekstist: helitu variant esines sagedamini pärast pausi ja helitut konsonanti ning heliline variant pärast vokaali ja helilist konsonanti. Helitu [h]-ga hääldatud juhtude hulka arvati ka kümmekond juhtu, kus mõni keelejuhtides hääldas vokaali ette kõrisulghääliku. Enamikul neist juhtudest jäi sõna pärast pausi.

Naiskeelejuhtide (KJ1-KJ4) ja meeskeelejuhtide (KJ5-KJ8) häälduse võrdlus näitab, et naiskeelejuhid hääldasid /h/-ga avalikus suhtluses $86 \%$ juhtudest ja meeskeelejuhid $80 \%$ juhtudest, mis näitab, et naised kontrollivad avalikus suhtluses hääldust rohkem kui mehed. Cui (1999) leidis, et see oli nii ka argisuhtluses, kuid siinsetel keelejuhtidel oli argisuhtluses /h/-ga hääldatud juhte kõigist juhtudest naistel vähem $(52 \%)$ kui meestel (66\%). Samas on meestel avaliku ja argisuhtluse vaheline erinevus väiksem kui naistel.

Joonisel 2 on näidatud sõnaalgulise /h/ hääldusvariantide osakaal kõigil keelejuhtidel avalikus (AVS) ja argisuhtluses (ARS).

Jooniselt 2 on näha, et osa keelejuhte hääldab avalikus suhtluses /h/ välja kas kõigil juhtudel (KJ5) või pea kõigil juhtudel (KJ2 94\%, KJ7 92\%, KJ4 91\%). Mõnevõrra väiksem on /h/ hääldamise osakaal keelejuhtidel KJ3 (86\%) ja KJ8 (75\%). Teistest keelejuhtidest vähem ehk ligikaudu pooltel juhtudel hääldavad /h/-d avalikus suhtluses KJ1 (51\%) ja KJ6 (48\%). 


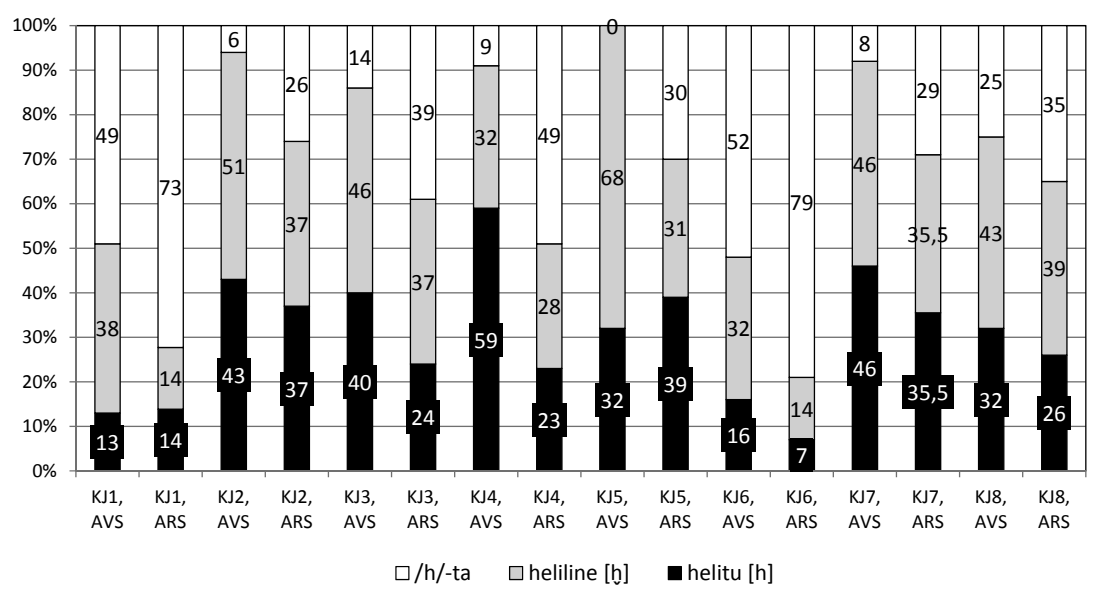

Joonis 2. Sõnaalgulise /h/ variandid kõigi keelejuhtide häälduses avalikus (AVS) ja argisuhtluses (ARS).

Kuigi keelejuhiti on hääldatud ja hääldamata /h/ osakaal avalikus suhtluses erinev, võib jooniselt 2 märgata, et kõik keelejuhid on siiski hääldanud /h/-d avalikus suhtluses rohkem kui argisuhtluses. Kolmel keelejuhil on $/ \mathrm{h} /$-ga hääldatud juhtude osakaal argisuhtluseski suhteliselt suur: KJ2 74\%, KJ7 71\%, KJ5 70\%. Kolmel keelejuhil on see neist mõnevõrra väiksem: KJ8 65\%, KJ3 61\% ja KJ4 51\%. Keelejuhtidel, kel avalikus suhtluses oli /h/ hääldamise osakaal teistest väiksem, on see nii ka argisuhtluses: KJ1 28\% ja KJ6 21\%.

\subsection{Sõna rõhulisuse ja esinemissageduse mõju sõnaalgulise /h/ hääldamisele}

Tabelis 2 on keelejuhiti ja kogu valimi kohta toodud nii avalikus kui ka argisuhtluses /h/-ga hääldatud sõnade osakaal sõna lauserõhulisusest ja sagedusest tulenevalt. Võrdluseks on esitatud keskmine /h/-ga hääldatud sõnade osakaal neis suhtlusolukordades. Selle ja kahe järgmise tabeli puhul tuleb arvestada asjaoluga, et keelejuhtidelt kogutud hääldusjuhte oli erineval hulgal (vt tabel 1) ning mõne osakaalu taga võib olla mõni üksik sõna. Andmed on esitatud osakaaludena, mitte absoluutarvudena selleks, et tulemused oleks keelejuhiti paremini võrreldavad. 


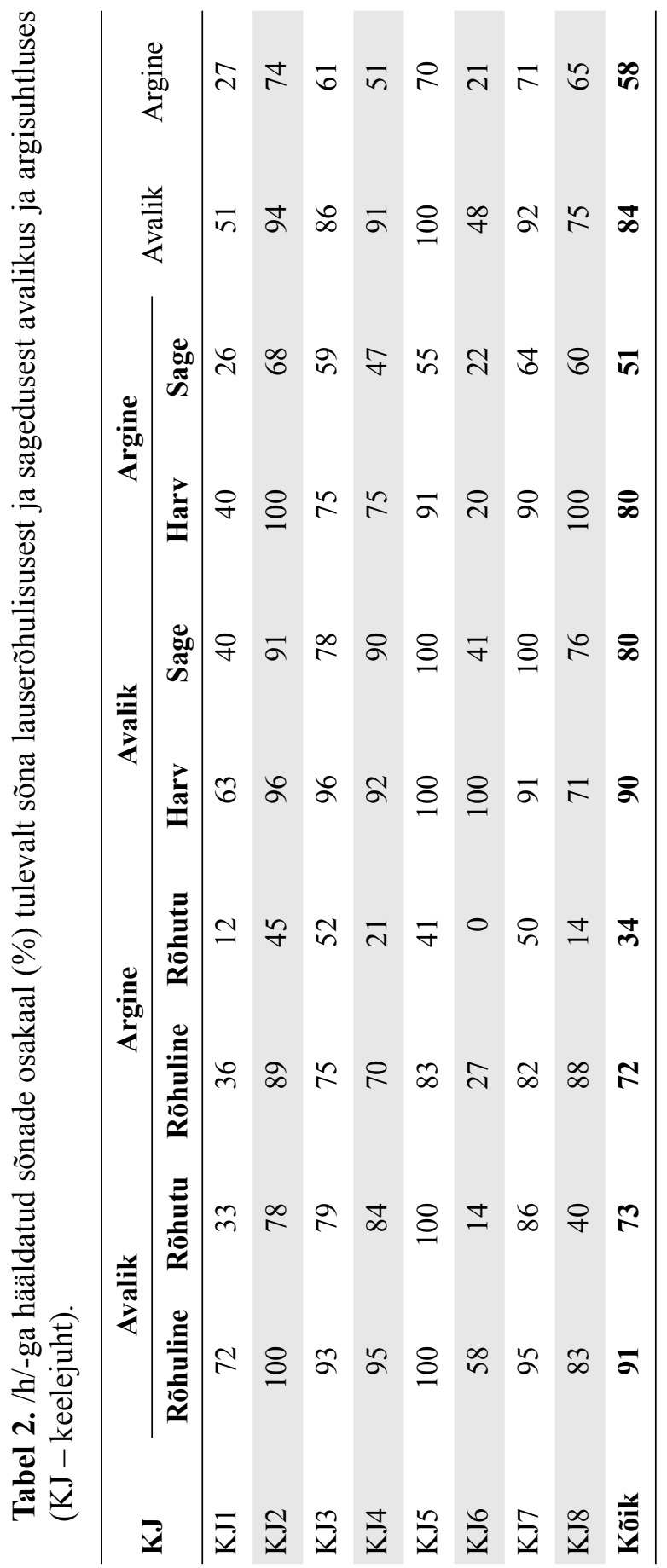


Pea kõigil keelejuhtidel on nii avalikus kui ka argisuhtluses /h/-ga häl̈ldatud sõnade osakaal rõhulistes sõnades tunduvalt suurem kui rõhututes sõnades (vt tabel 2): avaliku suhtluse rõhulistes sõnades on see 58-100\% ja rõhututes sõnades $14-86 \%$ (v.a KJ5), argisuhtluses vastavalt $27-88 \%$ ja $0-52 \%$. KJ5 hääldas avalikus suhtlusolukorras $h$-ga kõik sõnad nende rõhulisusest või ka järgnevalt analüüsitavatest muudest teguritest olenemata. Keelejuhtidel $\mathrm{KJ} 2, \mathrm{KJ} 3, \mathrm{KJ} 4, \mathrm{KJ} 7, \mathrm{KJ}$, kelle häälduses on /h/-ga hääldatud sõnade osakaal avalikus suhtluses 75-94\%, on see veel suurem, kui tegemist on rõhulise sõnaga: $83-100 \%$.

Argisuhtluses teistest rohkem /h/-d hääldanud keelejuhtidel KJ2, KJ5 ja KJ7 suurendab sõna rõhulisus veelgi /h/-ga hääldatud sõnade osakaalu, nii et see on $82-89 \%$ (kõigist juhtudest $70 \%-74 \%$ ). Keelejuhtidel KJ3, KJ4, KJ8, kes hääldasid argisuhtluses /h/-d eelmistest vähem (kõigist juhtudest 51-65\%), on rõhulistes sõnades samuti /h/-ga hääldatud sõnade osakaal suhteliselt suur: 70-88\%.

Sõna rõhulisus suurendab $/ \mathrm{h} /$ hääldamise osakaalu ka keelejuhtidel $\mathrm{KJ} 1$ ja KJ6, kes hääldasid /h/-d teiste keelejuhtidega võrreldes vähem nii avalikus kui ka argisuhtluses. KJ1 puhul on /h/-ga hääldatud juhtude osakaal avalikus suhtluses $51 \%$ ja argisuhtluses $27 \%$, kuid rõhulistes sõnades on see vastavalt $72 \%$ ja $36 \%$. Sama tendentsi võib märgata KJ6 häälduses, kus /h/-ga hääldatud juhte on suhtlusolukorrast tulenevalt $48 \%$ ja $21 \%$, kuid suhtlusolukorrast ja sõna rõhulisustest tulenevalt $58 \%$ ja $27 \%$.

Erinevalt sõna rõhulisusest paistab sõna esinemissagedus suurendavat /h/-ga hääldatud juhtude osakaalu rohkem argi- kui avalikus suhtluses (vt tabel 2): argisuhtluse väiksema esinemissagedusega sõnades on see $40-100 \%$ (v.a KJ6, kel erinevus puudub) ja suurema esinemissagedusega sõnades 26-68\%. Keelejuhtidel KJ2, KJ5, KJ7, kellel ongi argisuhtluses suhteliselt suur /h/-ga hääldatud sõnade osakaal (70-74\%), on see veel suurem harva esinevates sõnades: $90-100 \%$. Neist mõnevõrra väiksema $/ \mathrm{h} /$-ga hääldatud juhtude osakaaluga keelejuhtidel $\mathrm{KJ} 3$, KJ4 ja KJ8 (kõigist juhtudest 51-65\%), suurendab samuti sõna väiksem esinemissagedus /h/-ga hääldatud juhtude osakaalu: 75-100\%. Sama tendentsi on märgata KJ1 puhul: kõigist juhtudest /h/-ga hääldatud sõnu $27 \%$, väikse esinemissagedusega sõnadest aga $40 \%$. 
Avalikus suhtlusolukorras on osa keelejuhte sellised, kelle häälduses on väiksema esinemissagedusega sõnade hulgas rohkem /h/-ga häl̈ldatud juhte kui suurema esinemissagedusega sõnade hulgas: KJ1 $63 \%$ vs. $40 \%$, KJ3 96\% vs. $78 \%$ ja KJ6 100\% vs. 41\% (vt tabel 2). Muudel keelejuhtidel ei paista aga avalikus suhtluses sõna esinemissagedus /h/ hääldamist mõjutavat.

Varasemadki uurimused (Cui 1999 ja Mesipuu 2007) on näidanud sõna rõhulisuse mõju /h/ hääldamisele, mida võibki oodata, sest rõhulised sõnad on hääldatud täpsemalt, millele viitab nt ka nende pikem kogukestus võrreldes rõhutute sõnadega (vt nt Mihkla ja Sahkai 2017: 166). Lühike /h/ võib kaduda eelkõige argisuhtluses ka sõna seest vokaalide vahelt ning rõhututes sõnades toimub $/ \mathrm{h} / \mathrm{kadu}$ tunduvalt rohkem kui rõhulistes (vastavalt 34\% ja 15\% kõigist juhtudest, Teras 2018: 885). Varem on toodud välja ka sõna esinemissageduse mõju (nii Cui 1999 kui ka Mesipuu 2007). Kuna avalikus suhtluses on /h/ hääldamine järjekindlam, võibki seal oodata /h/ hääldamata jätmist eelkõige suure esinemissagedusega sõnades. Samas ei leidnud näiteks Kalvik ja Piits (2015: 67), et sõna esinemissagedus oleks mõjutanud /h/ hääldamist lugemisel, sest üksikutel juhtudel, kui /h/ hääldamata jäeti, võis see toimuda nii suure kui ka väikse esinemissagedusega sõna alguses. Küll näitas $/ \mathrm{h} /$ kestuste analüüs lühemat kestust suure esinemissagedusega sõnades (Kalvik ja Piits 2015: 66), mis näitab neis suuremat redutseerumist, mis omakorda võib viia /h/ kaoni.

\subsection{Sõna lausungiasukoha ja eelneva konteksti mõju sõnaalgulise /h/ hääldamisele}

Tabelis 3 on keelejuhiti ja kogu valimi kohta toodud avalikus ja argisuhtluses $/ \mathrm{h} /$-ga hääldatud sõnade osakaal protsentides tulenevalt sõna asukohast lausungis. Võrdluseks on toodud keskmine /h/-ga hääldatud sõnade osakaal neis suhtlusolukordades. 
Tabel 3. /h/-ga hääldatud sõnade osakaal (\%) tulevalt sõna asukohast lausungis avalikus ja argisuhtluses (KJ - keelejuht).

\begin{tabular}{lrrrrrrrr}
\hline \multirow{2}{*}{ KJ } & \multicolumn{7}{c}{ Avalik } & \multicolumn{3}{c}{ Argine } & \multirow{2}{*}{ Avalik } & Argine \\
\cline { 2 - 7 } & Alguses & Sees & Lõpus & Alguses & Sees & Lõpus & & \\
\hline KJ1 & 80 & 39 & 100 & 83 & 19 & 17 & 51 & 27 \\
KJ2 & 100 & 90 & 100 & 100 & 58 & 100 & 94 & 74 \\
KJ3 & 100 & 79 & 100 & 100 & 50 & 83 & 86 & 61 \\
KJ4 & 96 & 88 & 82 & 61 & 48 & 88 & 91 & 51 \\
KJ5 & 100 & 100 & 100 & 84 & 64 & 80 & 100 & 70 \\
KJ6 & 86 & 40 & 25 & 50 & 20 & 0 & 48 & 21 \\
\hline KJ7 & 100 & 89 & 100 & 88 & 61 & 75 & 92 & 71 \\
KJ8 & 100 & 74 & 0 & 100 & 62 & 67 & 75 & 65 \\
\hline Kõik & 95 & 78 & 85 & 82 & 50 & 70 & 84 & 58 \\
\hline
\end{tabular}

Sõna asukohast lausungis paistab nii avalikus kui ka argisuhtluses enim suurendavat /h/-ga hääldatud sõnade osakaalu lausungialgulisus ja mõne keelejuhi puhul ka lausungilõpulisus, nii et enim on $/ \mathrm{h} /$-ta hääldatud juhte lausungi sees. Kui kõigist hääldusjuhtudest on /h/-ga hälaldatud sõnade osakaal avalikus suhtluses $48-100 \%$ ja argisuhtluses $21-74 \%$, siis lausungialguliste sõnade puhul on see vastavalt $80-100 \%$ ja 50-100\%. Avalikus suhtluses on KJ1, KJ2, KJ3, KJ5, KJ7 hääldanud /h/-ga ka kõik lausungilõpulised sõnad. Argisuhtluses on enamikul keelejuhtidel lausungialguliste ja -lõpuliste sõnade hulgas /h/-ga hääldatud juhtude osakaal suurem kui lausungikesksete sõnade hulgas, kusjuures enamikul on /h/-ga hääldatud sõnade osakaal suurem lausungi alguses. Keelejuhtidel KJ1 ja KJ6 on rohkem /h/-ga hääldatud juhte lausungi alguses kui muudes asukohtades.

Tabelis 4 on keelejuhti ja kogu valimi kohta näidatud avalikus ja argisuhtluses /h/-ga hääldatud sõnade osakaal protsentides tulenevalt sõnale eelnevast kontekstist, milleks on kas paus, vokaal, heliline või helitu konsonant. Pausi järel olevad sõnad on ühtlasi ka lausungialgulised (vrd tabel 3), millest osa ei tule aga ette pärast pausi, vaid alustavad uut lausungit ilma pausita. Võrdluseks on toodud keskmine /h/-ga hääldatud sõnade osakaal neis suhtlusolukordades. 


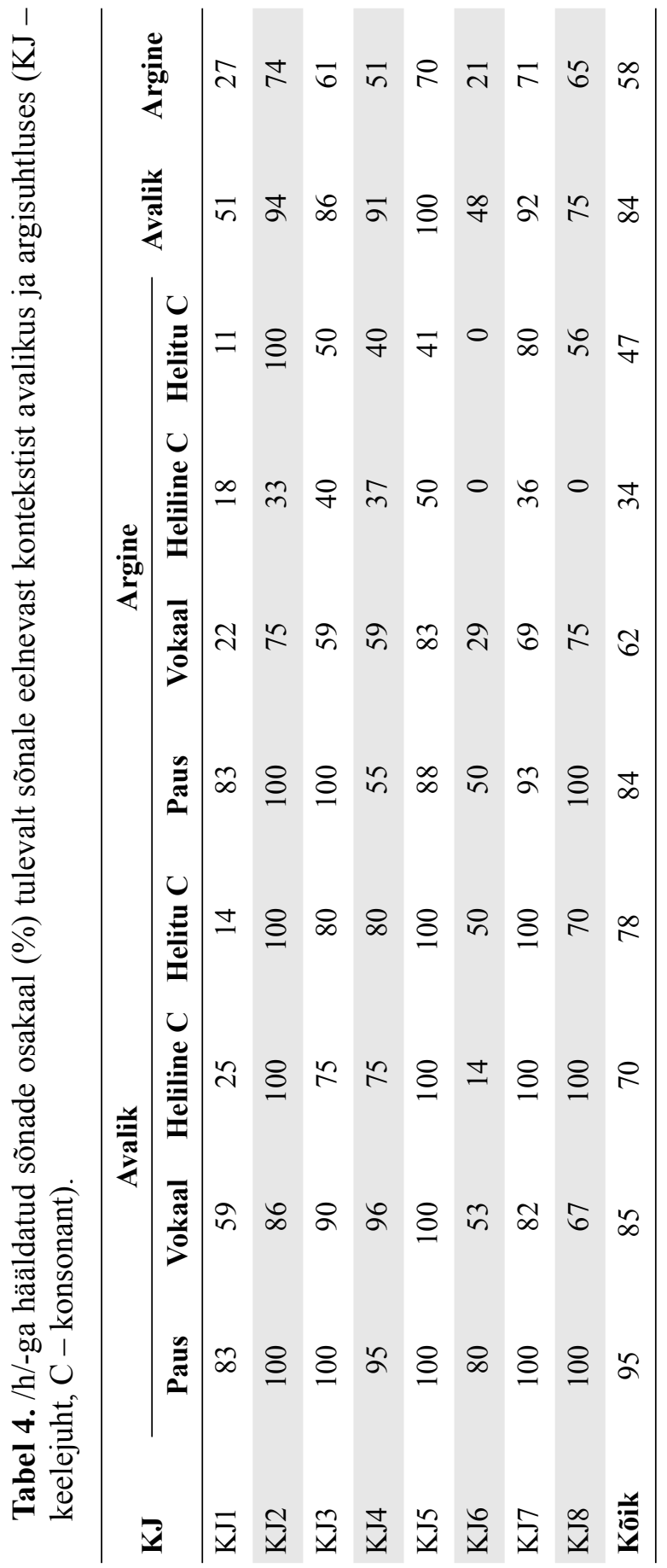


Vaadates $h$-algulisele sõnale eelnevat konteksti selgub, et avalikus suhtluses on keelejuhid hääldanud sõna /h/-ga pärast pausi $80-100 \%$ juhtudest, pärast vokaali 53-96\% juhtudest, pärast helilist või helitut konsonanti 14-100\% ja (v.a KJ5, kes hääldas kõik sõnad/h/-ga), argisuhtluses aga pärast pausi $50-100 \%$, pärast vokaali $22-83 \%$, pärast helilist konsonanti $0-50 \%$ ning pärast helitut konsonanti $0-100 \%$. Need vahemikud osutavad, et eelnev kontekst mõjutab $/ \mathrm{h} /$ hääldamist eri keelejuhtidel erinevalt.

Avalikus suhtluses suureneb /h/-ga hääldatud sõnade osakaal võrreldes selle osakaaluga kõigist juhtudest pärast pausi kõigil keelejuhtidel, pärast vokaali mõnevõrra mõnel keelejuhil (KJ1, KJ3, KJ4, KJ6) nagu ka pärast konsonanti (KJ2, KJ7) või ainult helilist konsonanti (KJ8).

Argisuhtluses on märgata samuti eelneva konteksti mõnevõrra erinevat mõju keelejuhtide hääldusele. Sealgi suureneb pea kõigil keelejuhtidel /h/-ga hääldatud juhtude osakaal pausi järel, kus see on 50-100\% (vrd kõigist juhtudest 21-74\%). Lisaks on enamikul keelejuhtidel /h/-ga häl̈ldatud sõnade osakaal suurem pärast vokaali kui pärast konsonanti, mõnel (KJ2, KJ7) aga pärast vokaali ja helitut konsonanti kui pärast helilist konsonanti.

Varem eesti keele kohta tehtud uurimustes ei ole pööratud tähelepanu sõna asukohale lausungis ning kontekstist ei ole pööratud tähelepanu pausile kui eelnevale kontekstile. Siinne uurimus näitab, et /h/-ga hääldatud sõnade osakaal on suurim nii üldiselt lausungi alguses kui ka pärast pausi. Selle asukoha tugevat mõju /h/ hääldamisele näitas ka saksa keele kohta tehtud uurimus, mille järgi $h$ võis küll üksikutel juhtudel jääda hääldamata, kuid mitte kunagi lausungi alguses (Zimmerer ja Trouvain 2015). Vokaalidevahelisegi lühikese $/ \mathrm{h} / \mathrm{kadu}$ toimub suhteliselt vähem lausungialgulistes ja -lõpulistes kui lausungisisestes sõnades (Teras 2018: 885). Sõnaalgulise /h/muude kontekstide puhul on osutatud, et $/ \mathrm{h} /-\mathrm{d}$ on hääldatud rohkem vokaali kui konsonandi järel (Cui 1999 ja Mesipuu 2007), kuid näiteks saksa keeles jäi /h/ hääldamata rohkem helitu konsonandi kui helilise hääliku järel (Zimmerer ja Trouvain 2015) ning hollandi keeles sulghääliku järel (Schuppler et al. 2011). Siinsete keelejuhtide puhul ei tulnud aga peale pausi muud konteksti, mis oleks /h/-ga hääldamist kõigil sarnaselt mõjutanud, kuid argisuhtluses paistab kõigil selleks olevad vokaaliga lõppev sõna, mille järel 
oli enamikul/h/-ga hääldatud juhte rohkem kui nt helilise konsonandi järel.

\section{3. /h/ hääldusvariantide klassifitseerimispuu}

Joonisel 3 on toodud $/ \mathrm{h} /$ hääldusvariantide kohta moodustatud klassifitseerimispuu, kust on näha, millised on /h/ hääldust mõjutavad olulisemad tegurid ja kuidas need esile tulid.

Klassifitseerimispuu esimene hargnemine näitab, et kõige tugevamalt ja kindlamalt on $/ \mathrm{h} /$ häälduse varieerumine seotud sõna rõhulisusega (1. sõlm $\left.{ }^{6}\right)$. Rõhute sõnade puhul tuleb esile tugev seos suhtlusolukorraga (2. sõlm) ning sealt omakorda avalikus suhtluses seos keelejuhiga (3. sõlm): keelejuhid $\mathrm{KJ} 1$ ja KJ6 on hääldanud avaliku suhtluse rõhutud sõnad enamasti /h/-ta, ülejäänud keelejuhid aga enamasti /h/-ga (sõlmed 4 ja 5); argisuhtluses on aga oluline seos eelneva kontekstiga (6. sõlm): pärast pausi olevad rõhutud sõnad on hääldatud enamasti $/ \mathrm{h} /$-ga, muudes kontekstides aga enamasti $/ \mathrm{h} /$-ta (sõlmed 7 ja 8).

Rõhuliste sõnade korral ilmneb kindlaim seos keelejuhiga (9. sõlm): KJ1 ja KJ6 häälduses on oluliselt vähem /h/-ga hääldatud rõhulisi sõnu kui teistel keelejuhtidel. Viimaste puhul tuleb esile tugev seos suhtlusolukorraga (10. sõlm): avalikus suhtluses on nad $h$-algulised rõhulised sõnad hääldanud ülekaalukalt /h/-ga (11. sõlm), argisuhtluses on aga näha lisaks seos positsiooniga (12. sõlm): lausungi alguses ja lõpus on /h/-ga hääldusvariante oluliselt rohkem kui lausungi sees (sõlmed 13 ja 14). KJ1 ja KJ6 rõhuliste sõnade puhul ilmneb seos eelneva kontekstiga (15. sõlm): /h/-ga hääldatud juhte on oluliselt rohkem pärast pausi ja vokaali (sõlm 19), pärast konsonanti on aga lisaseos sõnasagedusega (16. sõlm): seal on küll vähem hääldusjuhte, kuid need näitavad, et väiksema esinemissagedusega sõnade hulgas on /h/-ga hääldatud juhtude osakaal suurem, sagedad sõnad on aga hääldatud enamasti /h/-ta (sõlm 17 ja 18).

6 Inglise node näitab puul sõlme ehk tippu, kust hargnemine algab või kust see jätkub või kus see peatub. 


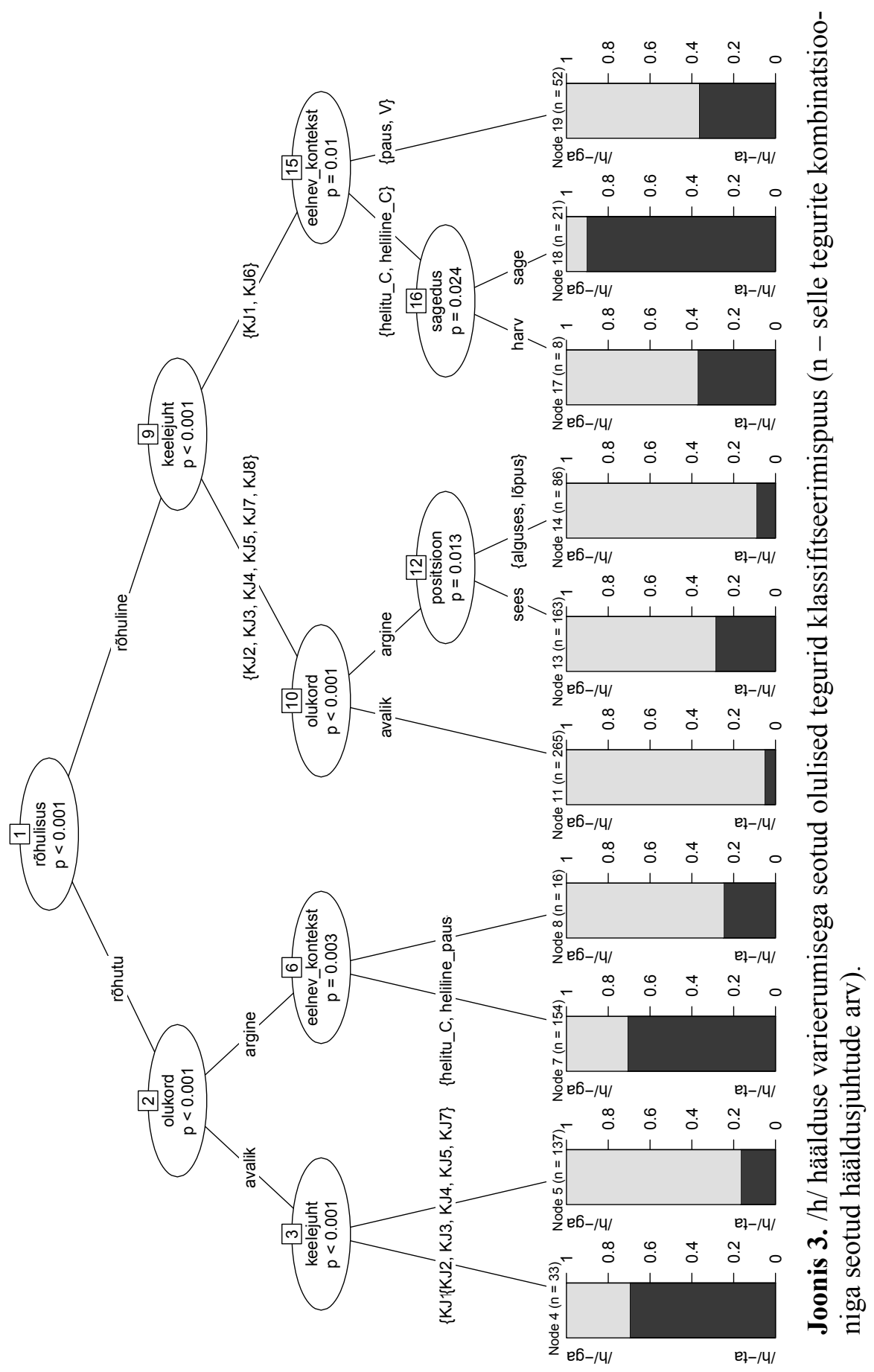


Selleks et leida, kas puu esitab andmeid hästi, koostati risttabel (vt tabel 5) prognoositud tõenäosustest ja tegelikest tulemustest (vt selle kohta Levshina 2015: 297).

Tabel 5. /h/-ga ja /h/-ga hääldatud juhtude prognoositud tõenäosused ja tegelikud tulemused.

\begin{tabular}{lcc}
\hline & /h/-ga & /h/-ta \\
\hline /h/-ga & 609 & 118 \\
/h/-ta & 57 & 151 \\
\hline
\end{tabular}

Tabel 5 näitab, et mudel prognoosib õigesti 760 juhtu ehk $81 \%$ kõigist 935 juhust, mis on rohkem kui juhuslik 50\%.

\section{Kokkuvõte}

Kõik kaheksa keelejuhti hääldasid sõnaalgulist /h/-d rohkem avalikus kui argisuhtluses, aga /h/-ga hääldatud sõnade osakaal varieerus keelejuhiti. Kui /h/ hääldati, siis oli see kas helitu [h] või heliline [h] (avalikus suhtluses vastavalt $44 \%$ ja $40 \%$ ning argisuhtluses $28 \%$ ja $30 \%$ kõigist hääldusjuhtudest). Nende variantide tekkimist soodustas loomulik häälikukontekst: helitu variant esines pärast pausi ja helitut häälikut ning heliline variant pärast helilist häälikut. /h/ jäi ametlikus ja argisuhtluses hääldamata vastavalt $16 \%$ ja $42 \%$ kõigist juhtudest.

Keelejuhtide hulgas oli neid, kellel oli /h/-ga hääldatud juhte avalikus suhtluses $100 \%$ (KJ5) või üle 90\% (KJ2, KJ7) ning kellel oli neid argisuhtluseski suhteliselt palju ehk $70 \%$ või veidi rohkem kõigist juhtudest (KJ2, KJ5, KJ7). Neist mõnevõrra vähem oli nii avalikus kui ka argisuhtluses /h/-ga hääldusjuhte keelejuhtidel KJ3 ja KJ8 (vastavalt $86 \%$ ja $75 \%$ ning $61 \%$ ja $65 \%$ ). Keelejuhil KJ4 oli suurem erinevus avaliku ja argisuhtluse vahel: esimeses oli /h/-ga hääldatud juhte üle 90\%, kuid viimases $51 \%$ juhtudest. Keelejuhtidel KJ1 ja KJ6 oli nii avalikus kui ka argisuhtluses /h/-ga hääldatud juhtude osakaal teistest tunduvalt väiksem (vastavalt 48-51\% ja 21-27\%). Need tulemused kinnitavad nii varasemaid tulemusi $h$-alguliste sõnade hääldamise kohta kui viitavad ka sellele, et selle uurimuse keelejuhid on üsna teadlikud sõnaalgulise /h/ hääldamise kuulumisest ametlikku suhtlusolukorda. 
Keelelistest teguritest tuli mõlemas suhtlusolukorras kõigi keelejuhtide häälduses järjekindlamalt esile sõna rõhulisuse mõju: /h/-ga hääldatud juhtude osakaal oli rõhuliste sõnade hulgas keskmisest suurem ning samuti tunduvalt suurem kui rõhutute sõnade hulgas. Samuti hääldasid keelejuhid (v.a KJ6) argisuhtluses /h/ sõna algusse keskmisest rohkem juhul, kui see jäi väiksema esinemissagedusega sõna algusse, kuid avalikus suhtluses sõna väiksem esinemissagedus kõigil keelejuhtidel/h/-ga hääldatud juhtude osakaalu ei suurendanud (nt KJ4, KJ7, KJ8).

Muudest teguritest oli järjekindlam sõna lausungialgulisuse mõju: lausungialgulistes sõnades hääldasid kõik keelejuhid /h/-d rohkem kui keskmiselt nii avalikus kui ka argisuhtluses. Samuti võis keelejuhiti suurendada /h/-ga hääldatud juhtude osakaalu sõna lausungilõpulisus (nt avalikus suhtluses KJ1, argisuhtluses KJ4, KJ5, mõlemas suhtlusolukorras KJ2, KJ3, KJ7). Lausungialgulisusega on seotud $h$-algulise sõna esinemine ka pärast pausi ning sealgi hääldasid kõik keelejuhid /h/-d keskmisest rohkem nii avalikus kui ka argisuhtluses. Samuti oli mitmel keelejuhil /h/-ga hääldatud juhtude osakaal keskmisest suurem vokaaliga lõppeva sõna järel ( $\mathrm{KJ} 1, \mathrm{KJ} 3$ avalikus suhtluses, $\mathrm{KJ} 5$, KJ8 argisuhtluses, KJ4, KJ6 mõlemas suhtlusolukorras). Keelejuhtidel KJ2 ja KJ7 oli aga /h/-ga hääldatud juhtude osakaal keskmisest suurem avalikus suhtluses pärast konsonandiga lõppevat sõna ja argisuhtluses pärast helitu konsonandiga lõppevat sõna.

Eri tegurite eraldi ja ühise mõju puhul tuli esile tugevaim ja kindlaim seos sõna lauserõhulisusega. Rõhulistes sõnades ilmses aga erinevus keelejuhtide vahel. Enamiku keelejuhtide puhul tuli esile oluline seos suhtlusolukorraga: avalikus suhtluses hääldati /h/ enamasti välja, argisuhtluses suurendas /h/-ga hääldatud juhtude osakaalu sõna asukoht lausungi alguses või lõpus. Keelejuhtide KJ1 ja KJ6 puhul oli aga rõhuliste sõnade hääldamisel seos eelneva konteksti ja sõna sagedusega: /h/-ga hääldatud juhte oli rohkem pärast pausi ja vokaali ning pärast konsonanti väikse esinemissagedusega sõnades. Rõhutute /h/-alguliste sõnade hääldamisel oli tugev seos suhtlusolukorraga. Avalikus suhtluses ilmnes sealjuures lisaseos keelejuhiga: enamik keelejuhte hääldas /h/-d enamikul juhtudel, keelejuhid KJ1 ja KJ6 hääldasid aga /h/-d seal teistest oluliselt vähem. Argisuhtluses tuli aga esile seos eelneva kontekstiga: /h/ osakaal oli rõhutute sõnade puhul suurem pärast pausi kui muudes kontekstides. 


\title{
Tänuavaldus
}

Uurimistöö on valminud riikliku programmi „Eesti keeletehnoloogia: Baastehnoloogiad ja -ressursid“ projekti EKTB3 „Eesti keele spontaanse kõne foneetilise korpuse arendused III" toel.

\author{
Aadress: \\ Pire Teras \\ Eesti ja üldkeeleteaduse instituut \\ Tartu Ülikool \\ Jakobi 2 \\ 51005 Tartu, Eesti \\ E-mail: pire.teras@ut.ee
}

\section{Kirjandus}

Alkire, Ti ja Carol Rosen (2010) Romance languages: a historical introduction. Cambridge University Press.

Ariste, Paul (1936) „Eesti praegune ühiskeele hääldus“. Eesti Kirjandus 5, 201-210.

Boersma, Paul ja David Weenink (2016) Praat: doing phonetics by computer. [Computer program]. Version 6.0.14. Kättesaadav aadressil $<$ http://www.praat.org/>. Alla laetud 11.02.2016.

Cui, Kaili (1999) Sõnaalguline h eesti keeles. Bakalaureusetöö käsikiri. Tartu: Tartu Ülikool. Eesti ja üldkeeleteaduse instituut.

Eek, Arvo ja Einar Meister (1999) „Estonian speech in the BABEL multilanguage database: phonetic-phonological problems revealed in the text corpus". Rmt-s Osamu Fujimura, Brian D. Joseph ja Bohumil Palek, toim. Proceedings of the Fourth Linguistics and Phonetics Conference (LP'98) 2, 529-546. Prague: The Karolinum Press.

Ehala, Martin (1998) Eesti kirjakeel. Gümnaasiumi õigekeelsusõpik. Künnimees.

EKK 2007 = Erelt, Mati, Tiiu Erelt, Kristiina Ross (2007) Eesti keele käsiraamat. Tallinn: EKI.

EKSKFK = Tartu Ülikooli eesti keele spontaanse kõne foneetiline korpus, 2019. Kättesaadav aadressil <https://www.keel.ut.ee/et/foneetikakorpus>. Vaadatud 03.07.2019.

Foneetikakorpuse sagedussõnastik, 2019. Kättesaadav aadressil $<$ http://datadoi.ut.ee/handle/33/93>. Vaadatud 03.07.2019.

Göseken, Heinrich (1660) Manuductio ad Linguam Oesthonicam. Anführung zur Öhstnischen Sprache, Bestehend nicht alleine in etlichen praeceptis und observationibus, Sondern auch In Verdolmetschung vieler Teutschen Wörter. Reval: Adolph Simon. 
Hint, Mati (2004) Eesti keele foneetika ja morfoloogia. Süvaõpik. 5., ümbertöötatud tr. Tallinn: Avita.

Hupel, August Wilhelm (1780) Ehstnische Sprachlehre für beide Hauptdialekte den revalschen und den dörptschen; nebst einem vollständigen Wörterbuch. Riga, Leipzig: J. F. Hartknoch.

Kalvik, Mari-Liis ja Liisi Piits (2015) „Lugemiseksperiment fonoloogilise varieerumise uurimiseks“. Eesti ja soome-ugri keeleteaduse ajakiri 6, 3, 97-122.

Kask, Arnold (1972) Eesti keele ajalooline grammatika 1. Häälikulugu. Teine trükk. Tartu: Tartu Riiklik Ülikool, eesti keele kateeder.

Kraut, Einar, Ene Liivaste ja Aili Tarvo (2000) Eesti õigekeel. Gümnaasiumi õigekeelsusõpik. Koolibri.

Levshina, Natalia (2015) How to do linguistics with R: data exploration and statistical analysis. Amsterdam, Philadelphia: John Benjamins.

Masing, Otto Wilhelm (1824) Beitrag zur Ehstnischen Ortographie. Dorpat: J. C. Schünmann.

Mesipuu, Margit (2007) Sõnaalguline h. Magistritöö käsikiri. Tartu: Tartu Ülikool. Eesti ja üldkeeleteaduse instituut.

Mihkla, Meelis ja Heete Sahkai (2017) „Lauserõhu akustilised korrelaadid eesti keeles“. Mäetagused 68, 161-176.

Pajusalu, Karl (1997) „Keskse perifeeria mõjust eesti keele tekkeloos“. Pühendusteos Huno Rätsepale 28.12.1997, 167-183. (Tartu Ülikooli eesti keele õppetooli toimetised, 7.) Tartu.

Paldre, Leho (1995) „Keel ja prestiiž“. Keel ja Kirjandus 6, 373-384.

PRÕK 2018 = Põhikooli riiklik õppekava. Lisa 1. Ainevaldkond „,Keel ja kirjandus“. Riigi Teataja, 2018. Kättesaadav aadressil $<$ https://www.riigiteataja.ee/akt/114022018008>. Vaadatud 03.07.2018.

Ramisch, Heinrich (2010) „Analysing linguistic atlas data: the (socio-) linguistic context of h dropping“. Dialectologia. Special issue 1, 175-184.

RStudio: Integrated development environment for $R$. [Computer software]. Boston, MA. Version 3.4.0. Kättesaadav aadressil <http://www.rstudio.org/>. Alla laetud 21.04.2017.

Ruutma, Mirjam, Aki-Juhani Kyröläinen, Maarja-Liisa Pilvik ja Kristel Uiboaed (2016) „Ambipositsioonide morfosüntaktilise varieerumise kirjeldusi kvantitatiivsete profiilide abil“. Keel ja Kirjandus 2, 92-113.

Schuppler, Barbara, Mirjam Ernestus, Odette Scharenborg ja Lou Boves (2011) „Acoustic reduction in conversational Dutch: a quantitative analysis based on automatically generated segmental transcriptions“. Journal of Phonetics 39, 1, 96-109.

Zimmerer, Frank ja Jürgen Trouvain (2015) „Production of /h/ in German: French vs. German speakers“. Proceedings of Interspeech 2015, 1922-1926.

Teras, Pire (2018) „The phonetic variation of short intervocalic /h/ in Estonian“. Proceedings of the 9th international conference on Speech Prosody, 883-887.

Viitso, Tiit-Rein ja Valts Ernštreits (2012) Lìvõkīel-estikiel-leţkiel sõnārōntõz (= Liivieesti-läti sõnaraamat $=$ Lībiešu-igauņu-latviešu vārdnīca). Ellen Niit, Karl Pajusalu ja Gunta Kḷava, toim. Riga, Tartu: Latviešu valodas aǵentūra, Tartu Ülikool. 


\begin{abstract}
Pire Teras: Pronunciation of word-initial /h/ by same speakers in formal and informal speech. In the present paper, the pronunciation of word-initial $/ \mathrm{h} /$ is considered. Previous research has pointed to the influence of the communicative situation: in informal speech $/ \mathrm{h} /$ is frequently dropped, but while reading texts and in formal speech this rarely happens. In addition, other factors influencing the pronunciation of $/ \mathrm{h} /$ have been found. However, no attention has been paid to how the same speaker pronounces the wordinitial $/ \mathrm{h} /$ in different communicative situations. This analysis of the pronunciation of eight speakers shows that all of them retained $/ \mathrm{h} / \mathrm{more}$ often in formal than in informal speech. The main factor influencing the pronunciation of $/ \mathrm{h} /$ is accentuation: $/ \mathrm{h} /$ is pronounced significantly more often in accented than in deaccented words. In the case of accented words, differences between speakers were found: two speakers dropped $/ \mathrm{h} /$ significantly more often $(/ \mathrm{h} /$ was more often retained after a pause, after a vowel-final word and in not frequent words), others pronounced it almost always in formal speech and in informal speech they used it more often in utterance initial and final words. In deaccented words, $/ \mathrm{h} /$ was significantly more often pronounced in formal speech (except for two speakers) and in informal speech after a pause.
\end{abstract}

Keywords: phonetics, word-initial/h/, variation, Estonian 